\title{
BTEX Exposure Assessment and Inhalation Health Risks to Traffic Policemen in the Klang Valley Region, Malaysia
}

\author{
Noor Fatihah Mohamad Fandi ${ }^{1}$, Juliana Jalaludin ${ }^{1,2 *}$, Mohd Talib Latif ${ }^{3}$, \\ Haris Hafizal Abd Hamid ${ }^{3}$, Mohd Fairus Awang ${ }^{1}$
}

\author{
${ }^{1}$ Department of Environmental and Occupational Health, Faculty of Medicine and Health Sciences, Universiti Putra \\ Malaysia, 43400 Serdang, Selangor, Malaysia \\ ${ }^{2}$ Department of Occupational Health and Safety, Faculty of Public Health, Universitas Airlangga, 60115 Surabaya, East \\ Java, Indonesia \\ ${ }^{3}$ Department of Earth Sciences and Environment, Faculty Science and Technology, Universiti Kebangsaan Malaysia, \\ 43600 Bangi, Selangor, Malaysia
}

\begin{abstract}
Benzene, toluene, ethylbenzene, $m, p$-xylene, and $o$-xylene (collectively referred to as BTEX), which are prevalent in the ambient air of urban environments, potentially cause chronic health effects, particularly among outdoor workers. Aim of this study was to evaluate BTEX concentrations in the Klang Valley of Malaysia and assess the health risks to urban traffic police officers, whose duties include controlling the traffic flow and enforcing traffic laws. Air samples were collected with low-flow personal samplers during the officers' work shifts outdoors, and the BTEX content was then analyzed via gas chromatography-mass spectrometry (GC-MS) coupled with thermal desorption (TD). A probabilistic method based on Monte Carlo simulation was applied to determine the cancer risk (CR) and hazard quotient (HQ), and a sensitivity analysis was performed to identify the greatest contributors to the estimated risks. The total BTEX concentration in the samples averaged $211.83 \mu \mathrm{g} \mathrm{m}^{-3}$, with the largest component being toluene (averaging $89.08 \mu \mathrm{g} \mathrm{m}^{-3}$ in concentration), followed by $m, p$-xylene $\left(37.25 \mu \mathrm{g} \mathrm{m}^{-3}\right), o$-xylene $\left(35.80 \mu \mathrm{g} \mathrm{m}^{-3}\right)$, benzene $\left(25.82 \mu \mathrm{g} \mathrm{m}^{-3}\right)$, and ethylbenzene $\left(23.89 \mu \mathrm{g} \mathrm{m}^{-3}\right)$. The average $\mathrm{CR}$ value for benzene $\left(5.31 \times 10^{-6}\right)$ as well as the $95^{\text {th }}$ percentiles of the $\mathrm{CR}$ values for benzene and ethylbenzene $\left(1.70 \times 10^{-5}\right.$ and $2.12 \times 10^{-6}$, respectively) exceeded the acceptable level of exposure $\left(1.0 \times 10^{-6}\right)$. The HQ values for all of the BTEX species were less than one. The sensitivity analysis revealed that the most influential parameter in increasing the estimated CR and HQ was the exposure duration, followed by the BTEX concentration. The estimated CR indicates that the prolonged exposure to benzene and ethylbenzene experienced by traffic police officers exacerbates the risk of adverse health effects. These results, which provide baseline data for determining the occupational risk to individuals who are exposed to BTEX while working on or near a road, emphasize the need for additional regulations, including the use of appropriate respiratory protective equipment.
\end{abstract}

Keywords: BTEX; Urban traffic police officers; Health risk assessment; Sensitivity analysis; Klang Valley.

\section{INTRODUCTION}

Volatile organic compounds (VOCs) are a prevalent group of air pollutants in urban and roadside areas. Benzene, toluene, ethylbenzene, and xylene, collectively known as $B T E X$, are mono-aromatic compounds in the VOC group. BTEX is continuously emitted from different natural and anthropogenic sources such as biogenic processes, paint application, evaporation from gasoline, industrial activities, solvent evaporation, biomass burning, and fuel combustion

\footnotetext{
* Corresponding author.

E-mail address: juliana@upm.edu.my
}

in motor vehicles (Lai et al., 2005; Williams and Koppmann, 2007; Kansal, 2009; Yuan et al., 2010; Yurdakul et al., 2013; Afshari et al., 2018). Vehicles are the most notable sources of BTEX emissions in urban areas in parallel with fast urban expansion leading to increased transport demand and fuel consumption. Previous studies have shown that mobile vehicle exhaust was a major influence on the levels of ambient BTEX in most urban and roadside areas (Ho et al., 2002; Wang et al., 2002; Jorquera and Rappenglück, 2004; Kerchich and Kerbachi, 2012; Afshari et al., 2018). Past literature has reported most light-duty vehicles (LDVs) used gasoline fuels (Liu et al., 2008; Tung et al., 2011; Cao et al., 2016). BTEX compounds were dominant in emissions from vehicles with gasoline fuel (Araizaga et al., 2013) while TEX were generated most from diesel-fuelled vehicles 
(Tsai et al., 2012). Elsewhere, Yao et al. (2015) reported benzene, toluene and $o$-xylene (BTX) were emitted from diesel-fuelled vehicles.

Indicators for BTEX emission sources are often determined using BTEX species ratios, such as toluene to benzene (T/B), $m, p$-xylene to ethylbenzene $(m, p-\mathrm{X} / \mathrm{E})$, xylene to benzene (X/B), and ethylbenzene to benzene (E/B) (Elbir et al., 2007; Hoque et al., 2008; Buczynska et al., 2009; Masih et al., 2016; Dehghani et al., 2018). T/B ratios within the range 1.5-4.3 exhibited mobile emissions as the original source in the studied region (Miri et al., 2016; Raysoni et al., 2017; Abtahi et al., 2018). Apart from that, T/B values are closely linked to heavy traffic (Latif et al., 2019). The ratios of $\mathrm{X} / \mathrm{B}, m, p-\mathrm{X} / \mathrm{E}$, and $\mathrm{E} / \mathrm{B}$ are indicative of photochemical reactivity or the so-called "freshness of air" an indicator of the age of air mass (Hsieh and Tsai, 2003; Zhang et al., 2008; Abtahi et al., 2018). The ratio of X/B and $\mathrm{E} / \mathrm{B}$ above one $(>1)$ and other reports the $m, p-\mathrm{X} / \mathrm{E}$ value more than 3.28 indicate that monitored air masses were photochemically young (Miller et al., 2011; Kerchich and Kerbachi, 2012; Bauri et al., 2016; Hajizadeh et al., 2018).

Concerns regarding human health in relation to BTEX exposure have grasped much attention due to their carcinogenic and mutagenic nature (ATSDR, 2007a, b, 2010; Esmaelnejad et al., 2015; ATSDR, 2017; Junaidi et al., 2019). BTEX compounds are likely responsible for chronic and acute health effects such as blood-related diseases (myeloid leukemia and aplastic anemia), potentially irreversible damage to the kidneys, cardiovascular disorder, nerve system disruption, headaches, and irritation to eye and skin (IARC, 1987; ATSDR, 2007a, b, 2010; Tunsaringkarn et al., 2012; Mohammadyan et al., 2016; ATSDR, 2017; Golkhorshidi et al., 2019). The concern of these harmful air contaminants is not limited only to public health but similar interest to the high-risk occupation such as outdoor workers. Outdoor workers such as traffic police officers are faced with the health risks of chronic BTEX exposure at the roadside. Houot et al. (2015) and Samadi et al. (2019) suggested that the occurrence of the possible adverse health effects on hematologic parameters and blood-related cancer was linked to heavy traffic density. Previous studies have documented an association between exposure to benzene emissions and risk of health impairments in traffic police (Arayasiri et al., 2010; Angelini et al., 2011; Carugno et al., 2012). Malaysian traffic police have a duty to regulate, control, and divert traffic and the majority of them work until their retirement. This means they are continuously exposed to toxic air pollutants while working in the middle of roads and are at risk of possible adverse health effects (Muhammad et al., 2012, 2014; Awang et al., 2018, 2019, 2020).

Currently, levels of BTEX have been reported from environmental monitoring (Lan and Binh, 2012; Norbäck et al., 2017; Hamid et al., 2019; Latif et al., 2019; Hamid et al., 2020); however, limited study has characterized the personal monitoring of these toxic compounds on outdoor workers such as traffic personnel in Malaysian urban areas. Personal sampling can represent the contaminant concentrations in the breathing zone and may more realistically reflect the true amounts of compounds inhaled to assess human exposure. Therefore, this study aims to determine the personal levels of BTEX inhaled by traffic police officers in cities in the Klang Valley and the potential health risks affecting them while they perform their outdoor duties. An estimation of cancer and non-cancer risks for BTEX exposure was performed using a Monte Carlo simulation technique together with a sensitivity analysis to determine which variables are the most influential. The BTEX species ratios were also examined from their individual monitoring samples to assess the major sources contributing to the levels of BTEX compounds in the cities of the Klang Valley.

\section{METHODS}

\section{Study Location}

The Klang Valley is an urban agglomeration which geographically covers an area of $2832 \mathrm{~km}^{2}$ and comprises Kuala Lumpur in the center and the regional context of Selangor, namely the towns of Gombak, Klang, Petaling Jaya, Shah Alam, Kuala Selangor, Kajang, and the district of Hulu Langat (Fig. 1). The cities within the Klang Valley region have a highly developed road network. LDVs such as motor cars dominate most cities within the Klang Valley region. As of 31 December 2017, the total number of motor vehicles in the Klang Valley region, covering Kuala Lumpur, Putrajaya, and Selangor state, was 8.3 million. A total of $92 \%$ of these registered vehicles were private vehicles (RTVM, 2017). The estimated population in the Klang Valley reached 7.4 million in 2017 and rose by approximately 1.3 hundred thousand the year after. Traffic police officers control the traffic flow and implement law enforcement at multiple points in the Klang Valley region according to their district's division. Vehicle type and the number of vehicles during peak hours (per hour) were reported in 2017 from the census stations in every district. These data can represent the studied areas as the traffic police officers perform the duties at the various points across these districts. These selected studied districts within the Klang Valley were Kuala Lumpur, Putrajaya, Petaling, Klang, Hulu Langat, and Gombak. Table S1 in Supplementary 1 shows the distinctive characteristics of the studied areas within the Klang Valley region.

\section{Study Subjects}

The subjects were among healthy male traffic police officers who worked within Klang Valley region. A total of 116 traffic policemen consisted of 49 of non-smokers and 67 of smokers were selected using a simple random sampling technique. They were between 20 to 58 years old with mean age of smokers and non-smokers were 33.0 and 32.6, respectively. The subjects were equipped with low-flow personal samplers attached to Tenax GR ${ }^{\circledR}$ tubes within the breathing zone area (an approximately 12-inch radius from the worker's nose and mouth). In this study, the traffic police officers were involved in controlling the traffic flow and performing law enforcement tasks during the morning, noon, and evening peak hours. Ethical approval for this study was obtained from the Ethics Committee for Research Involving Human Subjects, Universiti Putra Malaysia [FPSK(FR16)P004]. 


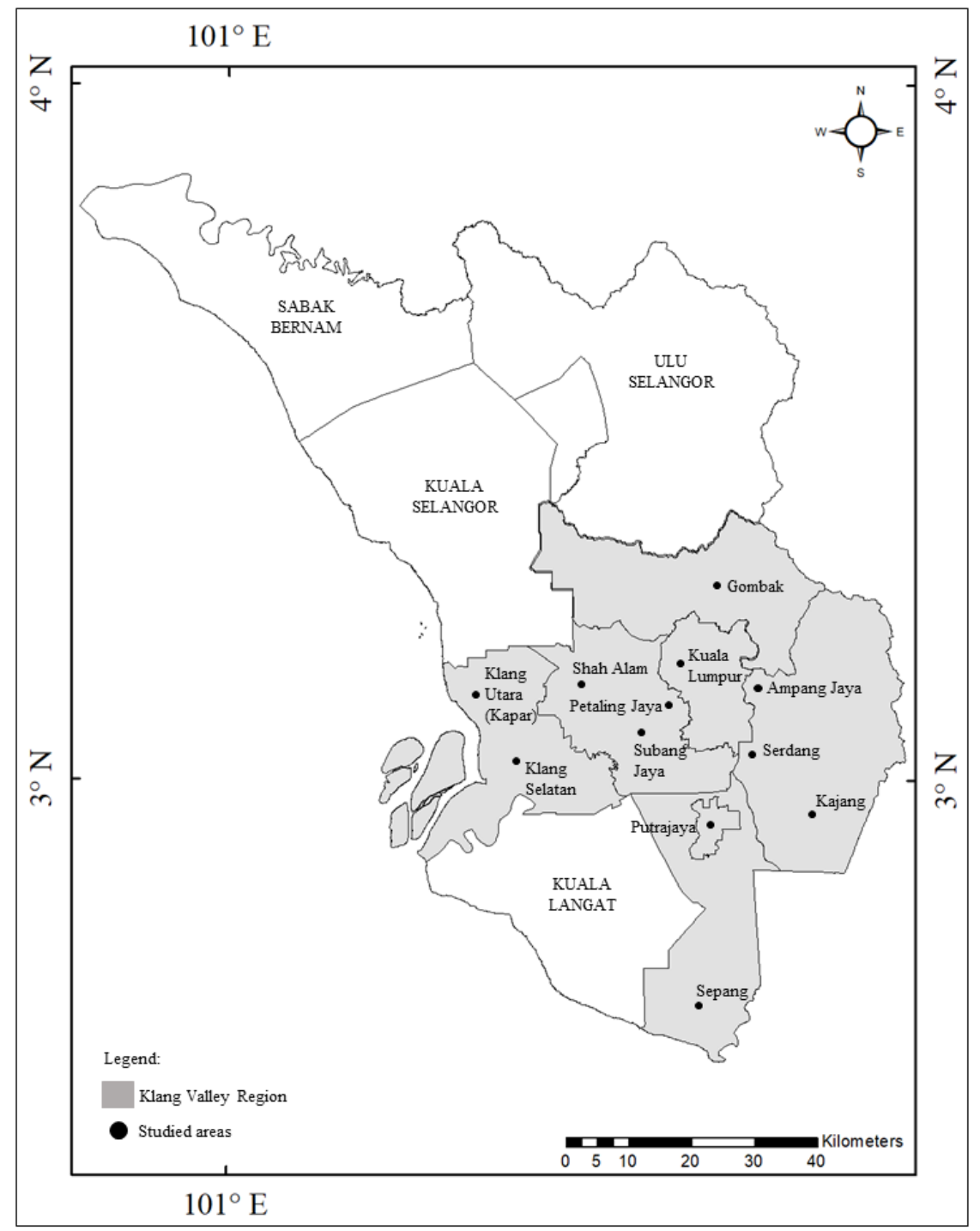

Fig. 1. The studied areas within the Klang Valley region.

\section{BTEX Personal Air Sampling}

The study was carried out from September 2017 to early January 2018. The BTEX samples were taken during the traffic policemen's working hours involving controlling traffic flow and enforcement tasks only. To ensure no other factors, e.g., smoking, affected the readings, this outdoor personal air sampling study was designed to minimize any confounders arising from smoking and/or passive smoking which may appear during different tasks during working time, especially during indoor activities.

The personal sampling was performed using an active sampling method with low-flow personal air samplers (PAS-500; Spectrex, USA) attached to a stainless-steel tube (89 mm [length] $\times 6.4 \mathrm{~mm}$ [internal diameter]) packed with Tenax ${ }^{\circledR}$ GR (Supelco, USA) sorbent. Samples were collected when the policemen were engaged in outdoor duties (expressed as an 8-h time-weighted average [TWA]) during working hours from 7:00-9:00 a.m., 10:00 a.m.-2:00 p.m. and 5:00-7:00 p.m., except in Kuala Lumpur city center (6:00 a.m. $-2: 00$ p.m.). The meteorological parameters such as temperature, relative humidity, and wind speed were recorded from the nearest air quality monitoring stations with an average of $28.73{ }^{\circ} \mathrm{C}, 76.95 \%$, and $1.062 \mathrm{~m} \mathrm{~s}^{-1}$, respectively. These air quality monitoring stations are located within a range of radius of approximately $4.5-25.9 \mathrm{~km}$ from the sampling areas. The pump was calibrated using an air flow calibrator (Primary Calibrator 4146; TSI Inc., USA) and set to a flow rate of $20 \mathrm{~mL} \mathrm{~min}^{-1}$ before and after personal sampling. The Tenax ${ }^{\circledR}$ GR tube was conditioned at $310^{\circ} \mathrm{C}$ for 40 min prior to sampling. The sorbent is a composite material consisting of $70 \%$ Tenax $^{\circledR}$ TA and $30 \%$ graphitized carbon. This sorbent tube is recommended for both passive and active sampling for measurements including benzene, toluene, ethylbenzene and xylene (Cao and Hewitt, 1993; Gelencsér et al., 1994; Tolnai et al., 2000; Kumar and Víden, 2007). Moreover, a hydrophobic sorbent such as Tenax ${ }^{\circledR}$ was used to minimize the humidity effect during the sampling (Gallego et al., 2010). Each subject was required to attach this equipment in the breathing zone while they performed their work tasks. The samples were capped and kept in the refrigerator at $4^{\circ} \mathrm{C}$ until analysis. 


\section{Sample Preparation and Analysis}

All sample tubes were analyzed for BTEX based on the established United States Environmental Protection Agency (U.S. EPA) TO-17 (1999) method for VOC measurement by active sampling onto sorbent tubes with some modifications (Hamid et al., 2019). Briefly, samples in the sorbent tube were directly analyzed via thermal desorption (TD; Unity-2 and Ultra-TD sampler; Markes International, UK) followed by a $6890 \mathrm{~N}$ gas chromatograph (GC) equipped with a mass spectrometry (MS) selective detector (Agilent Technologies, USA). A DB-624 (J\&W Scientific, USA) capillary column $(60 \mathrm{~m}$ [length] $\times 0.32 \mathrm{~mm}$ [i.d.] $\times 1.80 \mu \mathrm{m}$ [film thickness] was used for the BTEX separation. Details of the set-up parameters for the TD-GC-MS method are explained by Hamid et al. (2019) (Table S2 in Supplementary 2).

\section{Quality Control and Assurance}

Prior to the analysis, BTEX measurements were calibrated using 10-ppm BTEX standards (MESA, USA) diluted onto the sorbent tube using purified nitrogen $(0.9997 \%)$. Fivepoint calibrations were prepared between masses of 30 $450 \mathrm{ng}$ with the aid of a Calibration Solution Loading Rig (CSLR; Markes International). Calibration curve linearity for benzene, toluene, ethylbenzene, $m, p$-xylene and $o$-xylene were $0.9961,0.9977,0.9995,0.9998$ and 0.9995 , respectively. The limit of detection (LOD) for the BTEX compounds analyzed were $0.22,0.15,0.09,0.09$, and $0.09 \mu \mathrm{g} \mathrm{m}^{-3}$ for benzene, toluene, ethylbenzene, $m, p$-xylene, and $o$-xylene, respectively. A blank value (artefacts) for each tube was recorded after the recondition step and was found to be $<2 \mathrm{ng}$ except for benzene (10 ng). The artefact values were used to correct the results by subtracting them from the final mass. Quality assurance of the sampling process was undertaken by routinely checking the field blank tube (closed cap) which was deployed together with the samples. The results for field blanks suggested that all compounds were not affected by the background concentrations. Quality control (QC) was performed by the analysis of Certified Reference Standard (CRS) tubes (Markes International, UK) consist of $100 \mathrm{ng}$ BTX. The recovery QC results were $92 \%$ for benzene, $103 \%$ for toluene and $110 \%$ for $o$-xylene.

\section{Inhalation Health Risk Assessment}

The inhalation health risk assessment for cancer (CR) and non-cancer (known as the hazard quotient [HQ]) risks were determined using the U.S. EPA approach (1989). The information for health risk assessment (HRA) was obtained by questionnaire distribution during the sampling day. The HRA were able to calculate the nature and probability of the adverse health effects among the study population who were exposed to ambient BTEX pollutants now or in the future. Risk Assessment Guidance for Superfund Volume I: Human Health Evaluation Manual Parts A and F (U.S. EPA, 1989) were used for the risk assessment evaluation. The inhalation reference values for BTEX were obtained from the Risk Assessment Information System (RAIS) and the Integrated Risk Information System (IRIS) (U.S. EPA, 2007). The chronic daily intake (CDI) in units of $\mathrm{mg} \mathrm{kg}^{-1} \mathrm{~d}^{-1}$ (Eq. (3)) and exposure concentration (EC) in unit of $\mu \mathrm{g} \mathrm{m}^{-3}$ (Eq. (4)) were first estimated prior to further cancer risk (CR) (Eq. (1)) and non-cancer risk or hazard quotient (HQ) (Eq. (2)) calculations. In this study, the CR and HQ value for the BTEX were calculated as follows (Kanjanasiranont et al., 2017):

Cancer risk $(\mathrm{CR})=\mathrm{CDI} \times \mathrm{CSFi}$

Hazard quotient $(\mathrm{HQ})=\mathrm{EC} /(\mathrm{RfC} \times 1000)$

Chronic daily intake $(\mathrm{CDI})=(\mathrm{CA} \times \mathrm{IR} \times \mathrm{ET} \times \mathrm{EF} \times$ $\mathrm{ED}) /(\mathrm{BW} \times \mathrm{AT})$

Exposure concentration $(\mathrm{EC})=(\mathrm{CA} \times \mathrm{ET} \times \mathrm{EF} \times \mathrm{ED}) / \mathrm{AT}$

where:

$\mathrm{CA}\left(\mu \mathrm{g} \mathrm{m}^{-3}\right)$ Pollutant concentration in air (via personal sampling)

IR $\left(\mathrm{m}^{3} \mathrm{~h}^{-1}\right) \quad$ Inhalation rate $\left(0.875 \mathrm{~m}^{3} \mathrm{~h}^{-1}\right.$ for adults $)$ (U.S. EPA, 2011)

ET $\left(\mathrm{h} \mathrm{d}^{-1}\right) \quad$ Exposure time (working hours, $8 \mathrm{~h} \mathrm{~d}^{-1}$ )

$\mathrm{EF}\left(\mathrm{d} \mathrm{y}^{-1}\right) \quad$ Exposure frequency $\left(264 \mathrm{~d} \mathrm{y}^{-1}\right)$

ED (y) Exposure duration (mean \pm SD: $6.77 \pm$ 6.09 y; max: 24 y)

BW (kg) Body weight (mean \pm SD: $74.18 \pm$ $10.84 \mathrm{~kg}$ )

AT (d) Averaging time for cancer estimation: $70 \mathrm{y} \times 365 \mathrm{~d} \mathrm{y}^{-1}=25,550 \mathrm{~d}$

AT (h) Averaging time for non-cancer estimation: ED y $\times \mathrm{EF} \mathrm{d} \mathrm{y}^{-1} \times \mathrm{ET} \mathrm{h} \mathrm{d}^{-1}=50,688 \mathrm{~h}$

$\mathrm{CSFi} \quad$ Cancer slope factor

$\left(\mathrm{mg} \mathrm{kg}^{-1} \mathrm{~d}^{-1}\right)$ Benzene: $2.73 \times 10^{-2}$ (RAIS; U.S. EPA, 2007) Ethylbenzene: $3.85 \times 10^{-3}$ (RAIS; U.S. EPA, 2007)

RfC Inhalation reference concentration

$\left(\mathrm{mg} \mathrm{m}^{-3}\right) \quad$ Benzene: $3 \times 10^{-2}$ (RAIS; U.S. EPA, 2007)

Toluene: 5 (RAIS; U.S. EPA, 2007)

Ethylbenzene: 1 (RAIS; U.S.EPA, 2007)

Xylene: $1 \times 10^{-1}$ (RAIS; U.S. EPA, 2007)

A value of greater than $1 \times 10^{-6}$ for $\mathrm{CR}$ estimation is considered unacceptable while a HQ of equal or less than 1 is considered safe.

\section{Monte Carlo Simulation and Sensitivity Analysis}

A single-point input parameter used in risk assessment models could lead to uncertainty. Therefore, a probabilistic risk using the Montero Carlo simulation technique was applied in most risk assessment studies to reduce uncertainties (Zhang et al., 2017; Baghani et al., 2018; Miri et al., 2018; Gholizadeh et al., 2019; Mohammadi et al., 2020). This probabilistic approach uses a range of parameter value instead of a singlepoint value, and the risk estimation is repeated many times.

In this study, Monte Carlo simulations using Crystal Ball (version 11.1.2.4; Oracle Corp., USA) with 10,000 iterations have been applied to determine the inhalation risk to BTEX exposure. Meanwhile, the sensitivity analysis was conducted to determine which input parameters have the greatest influence on the estimated risk. The results of sensitivity analysis were 
reported as rank correlation coefficients and the input parameter that has a higher coefficient is the most contributor in risk uncertainty. The parameters used in health risk assessment of Monte Carlo simulation and sensitivity analysis were BTEX concentrations and ED with log-normal distribution (Jia et al., 2008; Zhou et al., 2011; Dai et al., 2017) and BW was in a normal distribution. Meanwhile, other necessary parameters such as IR, ET, EF, AT, CSFi, and RfC were in a fixed value (Golkhorshidi et al., 2019; Omidi et al., 2019).

\section{RESULTS AND DISCUSSION}

\section{Personal Exposure Levels to BTEX}

The daily exposure of outdoor traffic police officers to BTEX is shown in Table 1. The average total BTEX measured was $211.83 \mu \mathrm{g} \mathrm{m}^{-3}$. Toluene was found the most predominant among the BTEX species (the average concentration of toluene was $89.08 \mu \mathrm{g} \mathrm{m}^{-3}$ with a range of 15.13-444.47 $\mu \mathrm{g} \mathrm{m}^{-3}$ ). The means and standard deviations (SDs) of the concentrations of $m, p$-xylene, $o$-xylene, total xylene, benzene, and ethylbenzene were $37.25 \pm 24.37$, $35.80 \pm 21.65,73.04 \pm 44.50,25.82 \pm 18.84$, and $23.89 \pm$ $13.25 \mu \mathrm{g} \mathrm{m}^{-3}$ respectively. The relative abundances for the studied areas in the Klang Valley region among these urban workers were as follows: toluene $>$ xylene $>m, p$-xylene $>$ $o$-xylene $>$ benzene $>$ ethylbenzene. These rank similarly to reported ranks in others occupational populations in urban Thailand, the Philippines, China, and India (Majumdar et al., 2008; Balanay and Lungu, 2009; Tunsaringkarn et al., 2014; Chen et al., 2016). Similarly, studies utilizing ambient monitoring found the most abundant BTEX compound to be toluene observed in urban and roadside areas of Delhi, India (Hoque et al., 2008); Ashiya, Japan (Okada et al., 2012); Beijing, China (Li et al., 2014); Ho Chi Minh, Vietnam (Giang and Oanh, 2014); Gorakhpur and Northern India (Masih et al., 2016, 2017); and Kuala Lumpur, Malaysia (Hamid et al., 2019).

The high toluene levels found may be explained by fact that the content of toluene in unleaded gasoline is up to $15 \%$ by volume in Malaysia. Xylene showed the next highest exposure levels, followed by benzene, and the lowest was ethylbenzene. Safety data sheets published by petroleumbased companies showed most unleaded gasoline of RON95 and RON97 of the Euro 2 standard in Malaysia contains concentrations of benzene and ethylbenzene of up to $5 \%$ by volume, while xylene can reach $15 \%$ by volume. Tsai and
Chiang (2012), Ho et al. (2013), and Wang et al. (2017) found toluene to be the most abundant species in both lightduty gasoline- and diesel-fuelled vehicle emissions. These values illustrated the amounts of aromatic compounds released into the ambient air of urban traffic areas. The less reactive and stable benzene (a lifetime of 9.4 days) compared to ethylbenzene (1.6 days) also might explain the observed rank of these compounds in the atmosphere. Considering the maximum concentrations added to gasoline, these exhibited high levels comparable to the other countries such as Vietnam (toluene and benzene in RON95 were $1.85 \mathrm{wt} . \%$ and 4.2 wt.\%, respectively) (Lan and Minh, 2013). Malaysia is still unsuccessful in reaching the EPA-recommended limit of $0.6 \%$ by volume. Still, the oil specification of Euro $2 \mathrm{M}$ RON95 remains frequently consumed among LDV users in Malaysia. Hosaini et al. (2017) accounted a total of $94 \%$ BTEX emissions in the urban microenvironment from the vehicle emissions and gasoline evaporation. As of 31 December 2017, the number of motor vehicles showed a $5.4 \%$ increase in Malaysia (RTVM, 2017). The two-stroke engine motorcycle type contributes approximately half of the vehicle emissions in Malaysia, similar to those reported in Delhi (Hoque et al., 2008), and aromatic BTEX compounds are common VOCs released from motorcycle exhaust (Tsai et al., 2018).

A large number of traffic census stations within the studied areas were reported as in the F category (extreme, unacceptable congestion, stop-and-go traffic and forced flow) of the level of service (LOS) (RTVM, 2017). Moreover, these traffic census stations have also documented the category of cars was the highest on the road with the average ranged from 56.9 to $67.8 \%$, followed by motorcycles (12.8-22.6\%), van and utilities (5.4-11.8\%), medium lorries (4.6-6.7\%), heavy lorries $(2.1-4.1 \%)$, and buses $(0.2-0.6 \%)$. As reported in RTVM (2017), the average number of vehicles during peak traffic hour (per hour) was in the range between 2330 12,039 vehicles. This problematic street condition resulted in the subject inhaling more BTEX pollutants as most of them stood in the main traffic lane during the morning, noon, and evening rush hours with long lines of vehicles and congested traffic volume leading to traffic jams and increasing emissions from cars (Buczynska et al., 2009). Moreover, land cover in most of the cities of Klang Valley region is made up of tall buildings, trapping BTEX pollutants, and allowing them to accumulate along the roadsides. In agreement with this, levels of BTEX were found to reduce by around $15 \%$

Table 1. Detailed descriptive statistics of personal levels of BTEX $\left(\mu \mathrm{g} \mathrm{m}^{-3}\right)$ among traffic policemen $(\mathrm{n}=116)$ in the city of the Klang Valley.

\begin{tabular}{llllll}
\hline \multirow{2}{*}{ Pollutant } & \multicolumn{5}{c}{ Personal exposure level $\left(\mu \mathrm{g} \mathrm{m}^{-3}\right)$} \\
\cline { 2 - 5 } & Mean & SD & Median & Min & Max \\
\hline Benzene & 25.82 & 18.84 & 19.93 & 3.36 & 129.26 \\
Toluene & 89.08 & 60.88 & 76.81 & 15.13 & 444.47 \\
Ethylbenzene & 23.89 & 13.25 & 21.94 & 5.86 & 64.39 \\
m,p-Xylene & 37.25 & 24.37 & 31.93 & 0.97 & 133.66 \\
o-Xylene & 35.80 & 21.65 & 29.96 & 7.02 & 111.48 \\
Xylene & 73.04 & 44.50 & 64.05 & 14.82 & 245.14 \\
Total BTEX & 211.83 & 126.02 & 182.13 & 39.21 & 642.91 \\
\hline
\end{tabular}


for every $5 \mathrm{~m}$ downwind from the traffic lane (Giang and Oanh, 2014). Additional factors such as incomplete burning processes in old car engines without catalytic converters and less maintenance are also contributors for the increments in levels of BTEX as no end-of-life vehicle policy is implemented in Malaysia. Consequently, the urban traffic police officers had a higher risk of exposure to these toxic aromatic air pollutants as they directly inhaled the BTEX compounds emitted from vehicles.

A Mann-Whitney $U$ test showed no differences in the personal concentrations of BTEX between smokers and non-smokers. The smoker vs. non-smoker traffic policemen were exposed to benzene, toluene, ethylbenzene, $m, p$-xylene, $o$-xylene, and BTEX at levels (mean $\pm \mathrm{SD}$ ) of $26.46 \pm 20.58$, $89.61 \pm 53.41,23.87 \pm 12.95,35.60 \pm 22.66,35.68 \pm 21.95$, and $211.21 \pm 121.13 \mu \mathrm{g} \mathrm{m}^{-3}$ vs. $24.95 \pm 16.32,88.35 \pm$ $70.41,23.91 \pm 13.80,39.51 \pm 26.60,35.96 \pm 21.46$, and $212.67 \pm 133.70 \mu \mathrm{g} \mathrm{m}^{-3}$, with $p>0.05$, respectively. Smoking activity may affect the measurements; hence this study was designed to only measure the subject's outdoor activities. The traffic policemen were forbidden to smoke while performing their duties on the roads. These results indicated that both smoking and non-smoking traffic policemen were exposed to similar levels of BTEX during their outdoor duties.

The average individual BTEX compound exposure was lower than the present regulatory standards for BTEX occupational limits of $1.60,75.37,86.85$, and $434.19 \mathrm{mg} \mathrm{m}^{-3}$ of 8-h TWA from American Conference of Governmental Industrial Hygienists (ACGIH, 2011). However, the average level of benzene was much higher than the annual permissible limit of $5 \mu \mathrm{g} \mathrm{m}^{-3}$ established by the European Union (EU; European Commission, 2015). Vietnam is the only Asian country to set the hourly limits for benzene of $22 \mu \mathrm{g} \mathrm{m}^{-3}$ value reported here for average benzene slightly exceed this level. If the traffic police officers are consistently exposed to these levels of BTEX, standing at the roadside for most of their outdoor work shift for their working lifetime of years, then this poses a high risk to their health.

\section{Comparison with Previous Studies on BTEX Exposure among Outdoor Workers}

Comparing with outdoor urban workers worldwide, the order of toluene < xylene < benzene < ethylbenzene in this study was similarly observed in Bangkok's street vendors, Manila's jeepney drivers, China's taxi drivers, gasoline attendants in Kolkata, India, and Italian traffic police officers (Majumdar et al., 2008; Balanay and Lungu, 2009; Cattaneo et al., 2010; Tunsaringkarn et al., 2014; Chen et al., 2016). The majority of authors reported the highest exposure of toluene affected urban workers, except for security guards in Bangkok, Thailand (Tunsaringkarn et al., 2014; Kanjanasiranont et al., 2016). In Asia, the dominance of toluene in ambient air can be related to higher amounts of this compound mixed into petrol to increase its octane number. Toluene is proven as an effective antiknock additive for fuel and without it, ignition at lower temperatures is much harder. Ethylbenzene was detected at the lowest concentrations among urban workers' samples and this can be related to a content of a maximum of $5 \%$ by volume in most fuels. The fuel composition utilized also influences the levels of BTEX emitted, as well as from vehicle exhaust, car age, photochemical reactions, regional transportation of pollutants, and temperature (Lee et al., 2002; Chen et al., 2011; Ho et al., 2013).

Considering similar job tasks to this study, traffic police officers in Bangkok, Lebanon, and Peru were exposed to 1.9-16.5-fold higher and 2.4-2.7 times lower in Italian traffic police than the present study due to the carcinogenicity of benzene, respectively (Table 2) (Cattaneo et al., 2010; Campo et al., 2011; Han et al., 2013; Borgie et al., 2014; Kanjanasiranont et al., 2017). Such distinctive levels of benzene reported depending much more on the duration and time of sampling, the instrument used, areas of selection, distance from anthropogenic sources such as petrol pumps, traffic volumes, vehicle types, industrial sources and varying fuel compositions used in each country. The Italian petrol pump attendants were also markedly exposed to the highest benzene levels, and the majority of them had been exposed to benzene levels in the range $107.8-137.5 \mu \mathrm{g} \mathrm{m}^{-3}$ although lower concentrations were observed for Vietnamese petrol filling workers (Majumdar et al., 2008; Tunsaringkarn et al., 2012; Lan et al., 2013). Overall, traffic police officers and petrol pump attendants are exposed to high levels of total BTEX, more than $1000 \mu \mathrm{g} \mathrm{m}^{-3}$ (Majumdar et al., 2008; Borgie et al., 2014; Kanjanasiranont et al., 2017). These findings illustrate that traffic police officers and petrol pump attendants are more at risk than other outdoor workers due to the fact that they work around busy roads in the rush hours (Manuela et al., 2012), or pump an average of $2000 \mathrm{~L}$ petroleum with $5 \%(\mathrm{v} / \mathrm{v})$ benzene content during the 8 -h work shift (Çelık and Akbaş, 2005).

\section{Inter-species Correlation}

The inter-species correlations using the personal data collected were determined to examine the source indicators. Spearman's Rho correlation coefficients for BTEX species were evaluated as the data were not normally distributed (Table 3). Positive correlations were obtained when correlating the BTEX species with one another. A good correlation was found between all BTEX species ( $p<0.01$ and $r>0.80)$. These good correlation results indicate that these compounds originated primarily from a single source-vehicular emissions. The present findings seem to be consistent with others reported by Hoque et al. (2008), Miller et al. (2012), Rad et al. (2014), Miri et al. (2016), and Garg et al. (2018). Comparable to this study, correlation coefficients of $r<0.5$ were exhibited when the BTEX species are likely to originate from multiple sources of emissions other than just vehicle exhaust (Lee et al., 2002; Parra et al., 2006).

\section{Source Apportionment Using BTEX Ratio Species}

BTEX species ratios were calculated to determine the sources attributing to the levels of BTEX in this study (Table 4). The toluene-to-benzene (T/B) ratio showed the value of 3.81, indicating a source of traffic-related emissions. As observed, the average composition of vehicles (Table S1) documented in the year 2017 included more than 50\% cars and taxis, while motorcycles were the second-highest category 


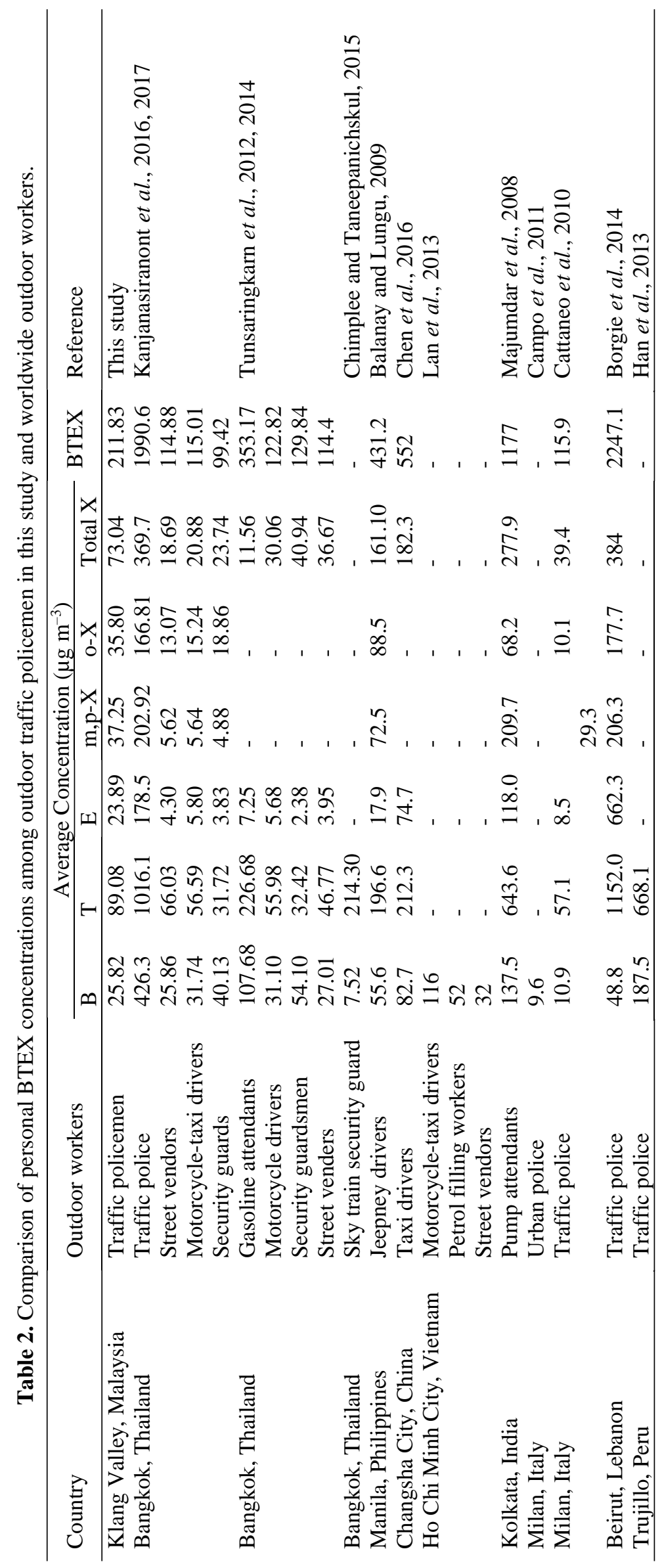


Table 3. Spearmen's Rho correlation for BTEX species.

\begin{tabular}{llllllll}
\hline & Benzene & Toluene & Ethylbenzene & m,p-Xylene & o-Xylene & xylene & BTEX \\
\hline Benzene & 1 & $0.841^{* *}$ & $0.845^{* *}$ & $0.863^{* *}$ & $0.880^{* *}$ & $0.908^{* *}$ & $0.910^{* *}$ \\
Toluene & & 1 & $0.857^{* *}$ & $0.854^{* *}$ & $0.863^{* *}$ & $0.890^{* *}$ & $0.968^{* *}$ \\
Ethylbenzene & & & 1 & $0.875^{* *}$ & $0.966^{* *}$ & $0.943^{* *}$ & $0.924^{* *}$ \\
m,p-Xylene & & & 1 & $0.889^{* *}$ & $0.962^{* *}$ & $0.924^{* *}$ \\
o-Xylene & & & & & 1 & $0.971^{* *}$ & $0.940^{* *}$ \\
xylene & & & & & & 1 & $0.966^{* *}$ \\
BTEXs & & & & & & 1 \\
\hline
\end{tabular}

** Correlation is significant at the level $p<0.01$.

Table 4. Ratio of BTEX species using personal concentration.

\begin{tabular}{lllllll}
\hline & & Mean & SD & Median & Min & Max \\
\cline { 2 - 7 } Individual & T/B & 3.81 & 2.02 & 3.56 & 1.56 & 14.28 \\
samples of & E/B & 1.04 & 0.31 & 0.46 & 0.39 & 0.44 \\
outdoor traffic & $\mathrm{m}, \mathrm{p}-\mathrm{X} / \mathrm{B}$ & 1.54 & 0.46 & 1.65 & 0.09 & 2.32 \\
policemen & $\mathrm{o}-\mathrm{X} / \mathrm{B}$ & 1.50 & 0.39 & 1.55 & 0.24 & 2.47 \\
(n=116) & $\mathrm{m}, \mathrm{p}-\mathrm{X} / \mathrm{E}$ & 1.54 & 0.44 & 1.53 & 0.10 & 2.94 \\
& $\mathrm{o}-\mathrm{X} / \mathrm{E}$ & 1.47 & 0.19 & 1.48 & 0.98 & 2.21 \\
\hline
\end{tabular}

of vehicle on the roads and highways. Most of the motorcycles were designed without any exhaust gas treatment system leading to these aromatic pollutants being given out to the ambient air (Lan and Binh, 2012). Also, it was reported that the total accumulated vehicles increased $5.5 \%$ in the year 2017 , of which $92 \%$ were private vehicles. LDVs such as cars and two-wheeled motor vehicles are common and dominate the traffic in Kuala Lumpur and other parts of the Klang Valley. This type of private LDV mostly run on Euro 2 gasoline. This $\mathrm{T} / \mathrm{B}$ result exhibited that the toluene and benzene components in gasoline are largely emitted to the atmosphere from this type of vehicle exhaust (Hajizadeh et al., 2018). Also, the traffic volumes during peak hours similar to the times traffic police officers were out for duty indicate they were exposed to over 2000 vehicles per hour. This traffic volume data and T/B ratio result confirm that mobile emissions are a vital source of aromatic species at the roadsides of the Klang Valley region, in which similarly reported by Latif et al. (2019). This finding is in agreement with Rad et al. (2014), Miri et al. (2016), Raysoni et al. (2017), Garg et al. (2018), and Hajizadeh et al. (2018) who found T/B ratios in the range 1.5-4.3. Previously, a lower T/B ratio (2.2) was reported by Lan and Binh (2012) in Kuala Lumpur from ambient air samples. Other roadside studies with intense traffic levels also showed almost similar T/B ratios to this; studies from Nanjing and Hong Kong, China, and Antwerp, Belgium, had averages of $\mathrm{T} / \mathrm{B}$ were $2.62,3.03$, and 3.83 respectively (Wang and Zhao, 2008; Buczynska et al., 2009; Huang et al., 2015). In contrast, T/B ratios of lower than one were reported from Xi'an, China; Gorakhpur, India; and Seoul, Korea (Na et al., 2003; Li et al., 2017; Masih et al., 2017). The provinces of Bangkok, Hong Kong, and Singapore recorded T/B ratios of $10.22,7.74$, and 6.2 respectively (Hoque et al., 2008; Lan and Binh, 2012). Elsewhere, the major road junctions in Ahmedabad region, India, showed the $\mathrm{T} / \mathrm{B}$ ratio was contributed from non-traffic sources (Sahu et al., 2016). These differences are possibly related to traffic volume, vehicle types, industrial sources, and varying fuel compositions utilized in each country (Lee et al., 2002; Wang and Zhao, 2008).

The ratios of $\mathrm{E} / \mathrm{B}, m, p-\mathrm{X} / \mathrm{B}, o-\mathrm{X} / \mathrm{B}, m, p-\mathrm{X} / \mathrm{E}$, and $o-\mathrm{X} / \mathrm{E}$ are useful to estimate the photochemical ages of air mass. The average $\mathrm{E} / \mathrm{B}, m, p-\mathrm{X} / \mathrm{B}, o-\mathrm{X} / \mathrm{B}, m, p-\mathrm{X} / \mathrm{E}$, and $o-\mathrm{X} / \mathrm{E}$ ratios from the roadside in this study were $1.04,1.54,1.50$, 1.54 , and 1.47 respectively. These lower ratio values indicate an aging air mass. Comparable to this study, Lan and Binh (2012) reported a value of $m, p-\mathrm{X} / \mathrm{B}$ ratio almost similar to this study $(>1)$ but a lower value for the $o-\mathrm{X} / \mathrm{B}$ ratio $(0.41)$. A clear distinction in $\mathrm{T} / \mathrm{B}, \mathrm{B} / \mathrm{E}, \mathrm{T} / \mathrm{E}$, and $\mathrm{X} / \mathrm{E}$ ratio results from intensive traffic roadsides can be seen from studies observed in Nanjing, China (2.62, 3.02, 7.90, and 1.18) (Wang and Zhao, 2008); Hong Kong, China (3.03, 1.75, 5.27, and 1.50) (Huang et al., 2015); Xi'an, China (0.36, 12.50, 4.37, and 2.73) (Li et al., 2017); and this study in the Klang Valley, Malaysia (3.81, 1.10, 3.83, and 3.01). These differences are probably influenced by variations of fuel composition use, meteorological conditions, photochemical reactions of BTEX species, vehicle technology, and location areas (Lan and Binh, 2012).

\section{Health Risk Assessment of BTEX and Sensitivity Analysis}

Apart from biological monitoring for benzene health outcome evaluation (Fandi et al., 2017), health risk assessment is a valid tool used to estimate cancer and non-cancer risks. The Monte Carlo simulation technique is widely used for estimating cancer and non-cancer risk of hazardous pollutant exposure in a variety of media (air, water, food, and soil) (Dai et al., 2017; Pérez-Maldonado et al., 2017; Fallahzadeh et al., 2018; Miri et al., 2018; Gholizadeh et al., 2019; Karami et al., 2019).

Figs. 2(a) and 2(b) depict the probability distribution of the predicted CR and HQ; meanwhile Fig. 2(c) shows the sensitivity analysis for the estimated risks of BTEX. The mean and $95^{\text {th }}$ percentile of $\mathrm{CR}$ values for benzene exposure 
(a)

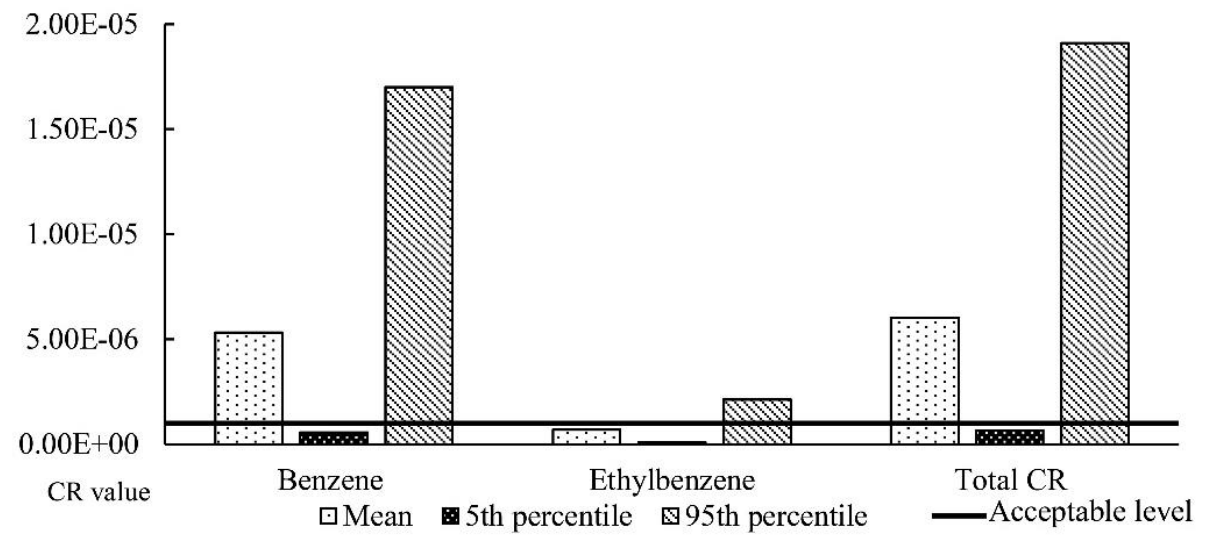

(b)

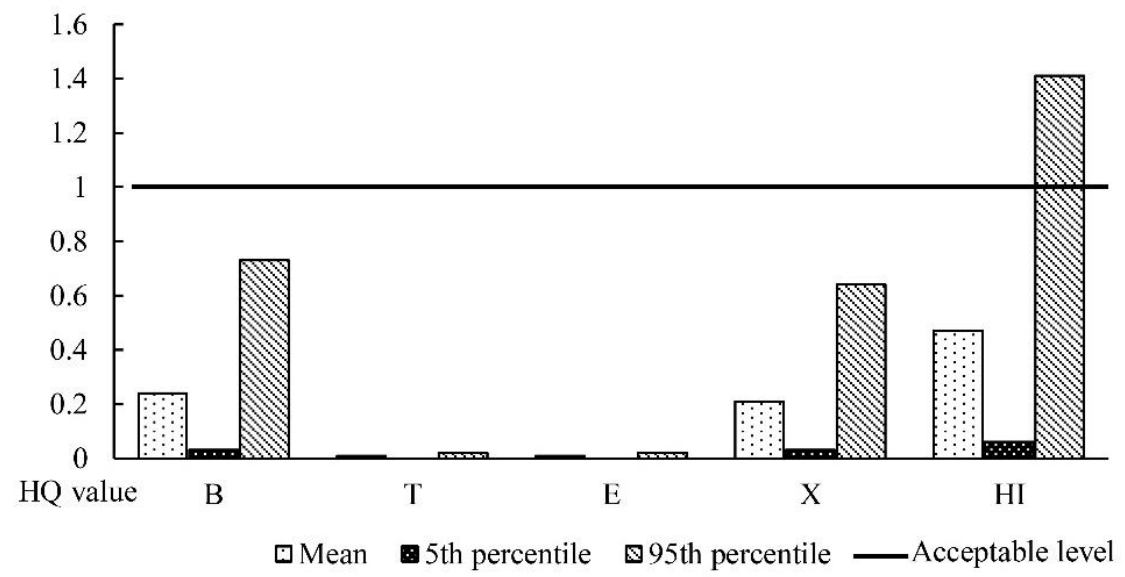

(c)
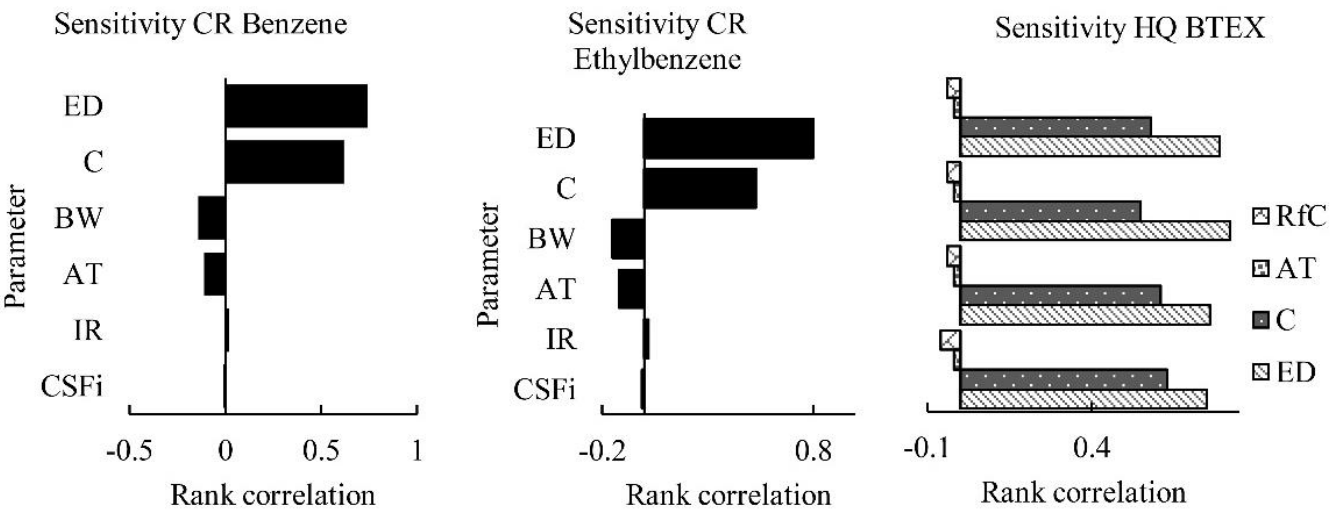

Fig. 2. Results of Monte Carlo simulations (a) (b) and sensitivity analyses (c) of CR (acceptable limit: $1.60 \times 10^{-6}$ ) and HQ (acceptable limit: 1) for BTEX exposure among traffic policemen (CR: Cancer risk; HQ: Hazard quotient; HI: Hazard index).

were $5.31 \times 10^{-6}$ and $1.70 \times 10^{-5}$, respectively. Meanwhile, the mean and $95^{\text {th }}$ percentile of CR calculated for ethylbenzene were $6.89 \times 10^{-7}$ and $2.12 \times 10^{-6}$, respectively. The mean of $\mathrm{CR}$ value for benzene was greater than the acceptable U.S. EPA limit $\left(1.6 \times 10^{-6}\right)$, even at a worst-case estimated risk of the $95^{\text {th }}$ percentile for both benzene and ethylbenzene. Mean and $95^{\text {th }}$ percentile total $\mathrm{CR}$ were at $6.00 \times 10^{-6}$ and $1.91 \times 10^{-5}$, respectively (Fig. 2(a)). Other studies had estimated the cancer risk for benzene exposure were much higher than the present study on average, ranged from $1.50 \times 10^{-4}$ to $7.68 \times 10^{-6}$ (Baghani et al., 2018; Mohammadi et al., 2019; Omidi et al.,
2019). On the contrary, Miri et al. (2016) had found the allowable level for benzene exposure $\left(3.94 \times 10^{-7}\right)$.

HQ values for BTEX ranged from 0.01 to 0.24 (mean) and in the range of $0.02-0.73$ at $95^{\text {th }}$ percentile. At both mean and $95^{\text {th }}$ percentile, the most abundant species for HQ was benzene $(0.24$ and 0.73$)$, followed by total xylene $(0.21$ and $0.64)$; meanwhile toluene, and ethylbenzene reported the similar and lowest results (0.01 and 0.02). All HQ values for BTEX were considered safe, which similarly reported by Miri et al. (2016) and Mohammadi et al. (2019). However, Omidi et al. (2019) reported an unacceptable limit of BTE 
(>1) among the studied workers. Summation of HQs for BTEX gave a total of 0.47 and 1.41 hazard index (HI) on average and $95^{\text {th }}$ percentile, respectively (Fig. 2(b)). The differences in CR and HQ values are likely to be mostly due to exposure time, location of their work or BTEX sampled, and types of duties.

Sensitivity analysis was performed to evaluate the most influential variable for the value of $\mathrm{CR}$ for benzene and ethylbenzene exposures and HQ values for BTEX exposure. The results of the sensitivity analysis of $\mathrm{CR}$ and HQ for BTEX were shown in Fig. 2(c). As can be seen that the exposure duration parameter has a greater impact on the $\mathrm{CR}$ values for benzene and ethylbenzene with a correlation coefficient of 0.74 and 0.80 , respectively, followed by the concentrations of benzene (0.62) and ethylbenzene (0.53). An inverse relationship appeared between body weight and $\mathrm{CR}$ value for benzene and ethylbenzene exposures (correlation coefficient: -0.14 and -0.15$)$, which similarly found by Miri et al. (2016). The present study also found that CR value was decreased with the increase of averaging time (correlation coefficient for $\mathrm{CR}$ benzene and ethylbenzene were -0.11 and -0.12 , respectively). An identical scenario was shown for the estimated BTEX HQ, in which exposure duration parameter had the highest impact in the uncertainty of HQ (range of correlation coefficient: $0.75-0.82$ ), followed by BTEX concentrations (ranged from 0.55 to 0.63 ). Meanwhile, averaging time (all values: 0.02) and inhalation reference concentration $(-0.04$ to -0.06$)$ were the lesser contributors, and both parameters had an inverse relationship with the BTEX HQ.

The traffic police officers can spend more than 20 years working at the roadsides without job task changes. This situation leads them to be exposed to extremely high levels of carcinogenic compounds, specifically benzene. Benzene is the most stable BTEX species, and it remains in the atmosphere the longest. The lifetime of $\mathrm{B}, \mathrm{T}, \mathrm{E}, o-\mathrm{X}, p-\mathrm{X}$ and $m$-X are as follows: 9.4 days $>1.9$ days $>1.6$ days $>$ $20.3 \mathrm{~h}>19.4 \mathrm{~h}>11.8 \mathrm{~h}$ (Monod et al., 2001). The longer lifetime and lesser reactivity of benzene means it can move to other regions without degradation. This shows the traffic police officers were chronically exposed to a cancer-causing agent as the depletion of benzene is negligible due to slow reactions with ozone $\left(\mathrm{O}_{3}\right)$ and nitrate $\left(\mathrm{NO}_{3}\right)$. The main target organ of benzene is bone marrow and can cause blood- related diseases. Therefore, the preventive measures are necessary for considering the duration of exposure at the roadsides to minimize the occupational hazard to BTEX as low as reasonably practicable.

The present study was emphasized only on the inhalation risk assessment and was limited for uncertainties such as exposure via ingestion and skin, including toxicology parameters. However, the different degree of the probability distribution with different range of conditions for input parameters were evaluated, instead of single-point estimated value.

\section{Risk Reduction Using Different Type of Respirators}

From the observation, a majority of traffic personnel did not wear respiratory protection, although the equipment was provided to them on a frequent basis. Moreover, they were frequently provided with a disposable half-mask, which were not appropriate for vapor pollutant filtration. To be recognized as a suitable respiratory protective equipment (RPE), the type of hazardous substances must first be identified before the correct RPE can be selected to ensure efficient protection to the users. The particulate filtration system was known for not being efficient to trap gases or vapor and vice versa for gas/vapor filter types because of the material differences made up (Health and Executive, 2013).

At $95^{\text {th }}$ percentile, the effectiveness of disposable dust face mask had shown a reduction in the incidence of cancer risk from $1.70 \times 10^{-5}$ to $3.40 \times 10^{-6}$ for benzene exposure; however, the value still considerably higher than an acceptable value. Even though the value of cancer risk decreases to the acceptable level $\left(2.12 \times 10^{-6}\right.$ to $\left.2.74 \times 10^{-7}\right)$ for ethylbenzene exposure, the provided dust mask only works for particle filtration. The incidence of benzene cancer risk reduced to $8.50 \times 10^{-7}$ and $1.70 \times 10^{-7}$ from 1.70 $\times 10^{-5}$ by using N95 face respirator and P100 facepiece respirator, respectively, in which $\mathrm{P} 100$ respirator incorporated a combination of vapor and particle filtration (Table 5).

Hence, the respirator that combines vapor and particle filtration system is proven to be efficient protective equipment for the case of benzene and ethylbenzene exposures. Nevertheless, BTEX exposure can be largely reduced by cutting down the emissions from transportation (source reduction) such as through the utilization of the fuel injection engines powered by ethanol-gasoline mixtures (Yao et al., 2017).

Table 5. Risk Reduction when using a different type of respiratory protective equipment (RPE) in outdoor traffic policemen.

\begin{tabular}{|c|c|c|c|c|c|}
\hline Risk Reduction (at $95^{\text {th }}$ & Benzene & $1.70 \times 10^{-5}$ & $3.40 \times 10^{-6}$ & $8.50 \times 10^{-7}$ & $1.70 \times 10^{-7}$ \\
\hline percentile) & Ethylbenzene & $2.12 \times 10^{-6}$ & $2.74 \times 10^{-7}$ & $1.20 \times 10^{-7}$ & $2.13 \times 10^{-8}$ \\
\hline Input value & & - & Conc. $\times 0.20$ & Conc. $\times 0.05$ & Conc. $\times 0.01$ \\
\hline Exposure reduction & & - & $80 \%$ & $95 \%$ & $99.7 \%$ \\
\hline Type of RPE & & $\begin{array}{l}\text { Without any } \\
\text { respiratory } \\
\text { protection }\end{array}$ & $\begin{array}{l}\text { Disposable Dust } \\
\text { Mask }\end{array}$ & $\begin{array}{l}\text { Face Respirator } \\
\text { N95 }\end{array}$ & $\begin{array}{l}\text { Facepiece } \\
\text { Respirator P100 } \\
\text { with particles + } \\
\text { vapors + gases } \\
\text { cartridge }\end{array}$ \\
\hline
\end{tabular}

Protection effectiveness increase 


\section{CONCLUSIONS}

This study assessed the personal BTEX exposure of traffic police officers working on or near the road during rush hour and the potential CR following chronic exposure. The total BTEX in the collected samples averaged $221.83 \mu \mathrm{g} \mathrm{m}^{-3}$ in concentration, and the following components, in descending order of average concentration, were detected: toluene $\left(89.08 \mu \mathrm{g} \mathrm{m}^{-3}\right)>$ total xylene $\left(73.04 \mu \mathrm{g} \mathrm{m}^{-3}\right)>m, p$-xylene $\left(37.25 \mu \mathrm{g} \mathrm{m}^{-3}\right)>o$-xylene $\left(35.80 \mu \mathrm{g} \mathrm{m}^{-3}\right)>$ benzene $\left(25.82 \mu \mathrm{g} \mathrm{m}^{-3}\right)>$ ethylbenzene $\left(23.89 \mu \mathrm{g} \mathrm{m}^{-3}\right)$. The highest concentration of toluene was related to its presence in vehicle fuel. Although all of the BTEX pollutants that we measured were in compliance with the ACGIH occupational limits, the level of ambient benzene exceeded both the average annual limit set by the EU and the average hourly limit stated in the Vietnamese National Air Quality Standard.

Strong correlations $(r>0.8)$ were found between the BTEX compounds, which, based on the T/B ratio (3.81), likely originated from traffic-related sources. Notably, unacceptably high $\mathrm{CR}$ values were calculated for benzene and ethylbenzene, which are classified as carcinogenic and probably carcinogenic, respectively, reflecting the serious health risks to urban traffic police officers. According to our probabilistic risk assessment, the exposure duration was the most significant contributor to incrementing the risk values, followed by BTEX concentration.

Our results support the inclusion of BTEX species as criteria pollutants in the National Ambient Air Quality Standard. The addition of these hazardous substances in fuel must be regulated, and we also recommend that traffic police officers be required to wear appropriate personal protective equipment, such as respirators fitted with organic vapor and particle cartridges. Future environmental health criteria assessments involving biological markers for specific BTEX pollutants should investigate aromatic BTEX species, which may offer potential clues on preventing BTEX-related illnesses.

\section{ACKNOWLEDGMENTS}

This work was supported by the Fundamental Research Grant Scheme 2016-2019 (No. 04-01-16-1808FR) funded by the Malaysian Ministry of Education and special thanks to Faculty Science Technology, Universiti Kebangsaan Malaysia, for their greatest contribution in facilities for BTEX air sample analysis, Malaysia Department of Occupational Safety and Health for sampling instruments aided and participation of traffic police officers in Klang Valley region with support of Bukit Aman Traffic Chief.

\section{SUPPLEMENTARY MATERIAL}

Supplementary data associated with this article can be found in the online version at https://aaqr.org/

\section{REFERENCES}

Abtahi, M., Fakhri, Y., Conti, G.O., Ferrante, M., Taghavi, M., Tavakoli, J., Heshmati, A., Keramati, H., Moradi, B.,
Amanidaz, N. and Khaneghah, A.M. (2018). The concentration of BTEX in the air of Tehran: A systematic review-meta analysis and risk assessment. Int. J. Environ. Res. Public Health 15: 1837. https://doi.org/10.3390/ijer ph15091837

ACGIH TLVs® and BEIs® (2011). Threshold limit values for chemical substances and physical agents biological exposure indices. American Conference of Governmental Industrial Hygienists. Cincinnati.

Afshari, A., Schuch, F. and Marpu, P. (2018). Estimation of the traffic related anthropogenic heat release using BTEX measurements - A case study in Abu Dhabi. Urban Clim. 24: 311-325. https://doi.org/10.1016/j.uclim.2017.02.001

Agency for Toxic Substances and Disease Registry (ATSDR) (2007a). Toxicological profile for benzene. Agency for Toxic Substances and Disease Registry, US Department of Health and Human Services, Atlanta, GA. Agency for Toxic Substances and Disease Registry (ATSDR) (2007b). Toxicological profile for xylene. Agency for Toxic Substances and Disease Registry, US Department of Health and Human Services, Atlanta, GA. Agency for Toxic Substances and Disease Registry (ATSDR) (2010). Toxicological profile for ethylbenzene. Agency for Toxic Substances and Disease Registry, US Department of Health and Human Services, Atlanta, GA. Agency for Toxic Substances and Disease Registry (ATSDR) (2017). Toxicological profile for toluene. Agency for Toxic Substances and Disease Registry, US Department of Health and Human Services, Atlanta, GA. Angelini, S., Kumar, R., Bermejo, J.L., Maffei, F., Barbieri, A., Graziosi, F., Carbone, F., Cantelli-Forti, G., Violante, F.S., Hemminki, K. and Hrelia, P. (2011). Exposure to low environmental levels of benzene: evaluation of micronucleus frequencies and S-phenylmercapturic acid excretion in relation to polymorphisms in genes encoding metabolic enzymes. Mutat. Res. Genet. Toxicol. Environ. Mutagen. 719: 7-13. https://doi.org/10.1016/j.mrgentox. 2010.10.002

Araizaga, A.E., Mancilla, Y. and Mendoza, A. (2013). Volatile organic compound emissions from light-duty vehicles in Monterrey, Mexico: A tunnel study. Int. J. Environ. Res. 7: 277-292. https://doi.org/10.22059/IJER. 2013.607

Arayasiri, M., Mahidol, C., Navasumrit, P., Autrup, H. and Ruchirawat, M. (2010). Biomonitoring of benzene and 1, 3-butadiene exposure and early biological effects in traffic policemen. Sci. Total Environ. 408: 4855-4862. https://doi.org/10.1016/j.scitotenv.2010.06.033

Awang, M.F., Jalaludin, J., Latif, M.T. and Fandi, N.F.M. (2018). Exposure to $\mathrm{PM}_{2.5}$ in urban area and respiratory health symptoms among urban workers in Klang Valley. IOP Conf. Ser.: Earth Environ. Sci 228: 1-6. https://doi.org/10.1088/1755-1315/228/1/012015

Awang, M.F., Jalaludin, J., Bakar, S.A. and Fandi, N.F.M. (2019). Exposure to $\mathrm{PM}_{2.5}$ and micronucleus frequency among traffic policemen in the urban areas of Klang Valley. Malaysian J. Med. Health Sci. 15: 101-102.

Awang, M.F., Jalaludin, J., Bakar, S.A., Latif, M.T., Fandi, N.F.M. and Abd Hamid, H.H. (2020). Assessment of 
micronucleus frequency and respiratory health symptoms among traffic policemen exposed to BTEX and $\mathrm{PM}_{2.5}$ in Klang Valley, Malaysia. Jurnal Teknologi 82: 73-82.

Baghani, A.N., Rostami, R., Arfaeinia, H., Hazrati, S., Fazlzadeh, M. and Delikhoon, M. (2018). BTEX in indoor air of beauty salons: Risk assessment, levels and factors influencing their concentrations. Ecotoxicol. Environ. Saf. 159: 102-108. https://doi.org/10.1016/j.ec oenv.2018.04.044

Balanay, J.A.G. and Lungu, C.T. (2009). Exposure of jeepney drivers in Manila, Philippines, to selected volatile organic compounds (VOCs). Ind. Health 47: 33-42. https://doi.org/10.2486/indhealth.47.33

Bauri, N., Bauri, P., Kumar, K. and Jain, V.K. (2016). Evaluation of seasonal variations in abundance of BTXE hydrocarbons and their ozone forming potential in ambient urban atmosphere of Dehradun (India). Air Qual. Atmos. Health 9: 95-106. https://doi.org/10.1007/s11869 $-015-0313-\mathrm{z}$

Borgie, M., Garat, A., Cazier, F., Delbende, A., Allorge, D., Ledoux, F., Courcot, D., Shirali, P. and Dagher, Z. (2014) Traffic-related air pollution. A pilot exposure assessment in Beirut, Lebanon. Chemosphere 96: 122-128. https://doi.org/10.1016/j.chemosphere.2013.09.034

Buczynska, A.J., Krata, A., Stranger, M., Godoi, A.F.L., Kontozova-Deutsch, V., Bencs, L., Naveau, I., Roekens, E. and Van Grieken, R. (2009). Atmospheric BTEXconcentrations in an area with intensive street traffic. Atmos. Environ. 43: 311-318. https://doi.org/10.1016/j.at mosenv.2008.09.071

Campo, L., Cattaneo, A., Consonni, D., Scibetta, L., Costamagna, P., Cavallo, D.M., Bertazzi, P.A. and Fustinoni, S. (2011). Urinary methyl tert-butyl ether and benzene as biomarkers of exposure to urban traffic. Environ. Int. 37: 404-411. https://doi.org/10.1016/j.envi nt.2010.11.002

Cao, X., Yao, Z., Shen, X., Ye, Y. and Jiang, X. (2016). Onroad emission characteristics of VOCs from light-duty gasoline vehicles in Beijing, China. Atmos. Environ. 124: 146-155. https://doi.org/10.1016/j.atmosenv.2015.06.019

Cao, X.L. and Hewitt, C.N. (1993). Thermal desorption efficiencies for different adsorbate/adsorbent systems typically used in air monitoring programmes. Chemosphere 27: 695-705. https://doi.org/10.1016/00456535(93)90002-M

Carugno, M., Pesatori, A.C., Dioni, L., Hoxha, M., Bollati, V., Albetti, B., Byun, H.M., Bonzini, M., Fustinoni, S., Cocco, P., Satta, G., Zucca, M., Merlo, D.F., Cipolla, M., Bertazzi, P.A. and Baccarelli, A. (2012). Increased mitochondrial DNA copy number in occupations associated with low-dose benzene exposure. Environ. Health Perspect. 120: 210-215. https://doi.org/10.1289/e hp. 1103979

Cattaneo, A., T aronna, M., Consonni, D., Angius, S., Costamagna, P. and Cavallo, D.M. (2010). Personal exposure of traffic police officers to particulate matter, carbon monoxide, and benzene in the city of Milan, Italy. J. Occup. Environ. Hyg. 7: 342-351. https://doi.org/10.1 080/15459621003729966
Çelık, A. and Akbaş, E. (2005). Evaluation of sister chromatid exchange and chromosomal aberration frequencies in peripheral blood lymphocytes of gasoline station attendants. Ecotoxicol. Environ. Safe. 60: 106-112. https://doi.org/10.1016/j.ecoenv.2003.10.008

Chen, X., Feng, L., Luo, H. and Cheng, H. (2016). Health risk equations and risk assessment of airborne benzene homologues exposure to drivers and passengers in taxi cabins. Environ. Sci. Pollut. Res. 23: 4797-4811. https://doi.org/10.1007/s11356-015-5678-x

Chen, X., Zhang, G., Zhang, Q. and Chen, H. (2011). Mass concentrations of BTEX inside air environment of buses in Changsha, China. Build. Environ. 46: 421-427. https://doi.org/10.1016/j.buildenv.2010.08.005

Chimplee, T. and Taneepanichskul, N. (2015). Benzene and toluene exposure in relation to their health effects among sky-train station guards in Bangkok, Thailand. J. Health Res. 29: 177-184. https://doi.org/10.14456/jhr.2015.66

Dai, H., Jing, S., Wang, H., Ma, Y., Li, L., Song, W. and Kan, H. (2017). VOC characteristics and inhalation health risks in newly renovated residences in Shanghai, China. Sci. Total Environ. 577: 73-83. https://doi.org/10.1016/j. scitotenv.2016.10.071

Dehghani, M., Fazlzadeh, M., Sorooshian, A., Tabatabaee, H.R., Miri, M., Baghani, A.N., Delikhoon, M., Mahvi, A.H. and Rashidi, M. (2018). Characteristics and health effects of BTEX in a hot spot for urban pollution. Ecotoxicol. Environ. Saf. 155: 133-143. https://doi.org/1 0.1016/j.ecoenv.2018.02.065

Elbir, T., Cetin, B., Cetin, E., Bayram, A. and Odabasi, M. (2007). Characterization of volatile organic compounds (VOCs) and their sources in the air of Izmir, Turkey. Environ. Monit. Assess. 133: 149-160. https://doi.org/10. 1007/s10661-006-9568-Z

Esmaelnejad, F., Hajizadeh, Y., Pourzamani, H. and Amin, M.M. (2015). Monitoring of benzene, toluene, ethyl benzene, and xylene isomers emission from Shahreza gas stations in 2013. Int. J. Environ. Health Eng. 4: 17-17. https://doi.org/10.4103/2277-9183.157716

European Commission (2015). Air quality standards. https://ec.europa.eu/environment/air/quality/standards.htm

Fallahzadeh, R.A., Miri, M., Taghavi, M., Gholizadeh, A., Anbarani, R., Hosseini-Bandegharaei, A., Ferrante, M. and Conti, G.O. (2018). Spatial variation and probabilistic risk assessment of exposure to fluoride in drinking water. Food Chem. Toxicol. 113: 314-321. https://doi.org/10.10 16/j.fct.2018.02.001

Fandi, N.F.M., Suhaili, A. and Juliana, J. (2017). Assessing biomarkers on exposure, effects and susceptibility for environmental and occupational exposure of various range of benzene. Malaysian J. Public Health Med. 1: 718. http://psasir.upm.edu.my/id/eprint/60931/

Gallego, E., Roca, F.J., Perales, J.F. and Guardino, X. (2010). Comparative study of the adsorption performance of a multi-sorbent bed (Carbotrap, Carbopack X, Carboxen 569) and a Tenax TA adsorbent tube for the analysis of volatile organic compounds (VOCs). Talanta 81: 916924. https://doi.org/10.1016/j.talanta.2010.01.037

Garg, A., Gupta, N.C. and Tyagi, S.K. (2018). Levels of 
benzene, toluene, ethylbenzene, and xylene near a trafficcongested area of east Delhi. Environ. Claims J. 31: 5-15. https://doi.org/10.1080/10406026.2018.1525025

Gelencsér, A., Kiss, G., Hlavay, J., Hafkenscheid, T.L., Peters, R.J.B. and De Leer, E.W.B. (1994). The evaluation of a tenax GR diffusive sampler for the determination of benzene and other volatile aromatics in outdoor air. Talanta 41: 1095-1100. https://doi.org/10.1016/00399140(94)80077-4

Gholizadeh, A., Taghavi, M., Moslem, A., Neshat, A.A., Najafi, M.L., Alahabadi, A., Ahmadi, E., Ebrahimi aval, H., Asour, A.A., Rezaei, H., Gholami, S. and Miri, M. (2019). Ecological and health risk assessment of exposure to atmospheric heavy metals. Ecotoxicol. Environ. Saf. 184: 109622. https://doi.org/10.1016/j.ecoenv.2019.109622

Giang, N.T.H. and Oanh, N.T.K. (2014). Roadside levels and traffic emission rates of $\mathrm{PM}_{2.5}$ and BTEX in Ho Chi Minh City, Vietnam. Atmos. Environ. 94: 806-816. https://doi.org/10.1016/j.atmosenv.2014.05.074

Golkhorshidi, F., Sorooshian, A., Jafari, A. J., Baghani, A. N., Kermani, M., Kalantary, R. R., Ashournejad, Q. and Delikhoon, M. (2019). On the nature and health impacts of BTEX in a populated middle eastern city: Tehran, Iran. Atmos. Pollut. Res. 10: 921-930. https://doi.org/10.1016/ j.apr.2018.12.020

Hajizadeh, Y., Mokhtari, M., Faraji, M., Mohammadi, A., Nemati, S., Ghanbari, R., Abdolahnejad, A., Fard, R.F., Nikoonahad, A., Jafari, N. and Miri, M. (2018). Trends of BTEX in the central urban area of Iran: A preliminary study of photochemical ozone pollution and health risk assessment. Atmos. Pollut. Res. 9: 220-229. https://doi.org/ 10.1016/j.apr.2017.09.005

Hamid, H.H.A., Latif, M.T., Nadzir, M.S.M., Uning, R., Khan, M.F. and Kannan, N. (2019). Ambient BTEX levels over urban, suburban and rural areas in Malaysia. Air Qual. Atmos. Health 12: 341-351. https://doi.org/10. 1007/s 11869-019-00664-1

Hamid, H.H.A., Latif, M.T., Uning, R., Nadzir, M.S.M., Khan, M.F., Ta, G.C. and Kannan, N. (2020). Observations of BTEX in the ambient air of Kuala Lumpur by passive sampling. Environ. Monit. Assess. 192: 342. https://doi.org/ 10.1007/s10661-020-08311-4

Han, X., Aguilar-Villalobos, M., Allen, J., Carlton, C.S., Robinson, R., Bayer, C. and Naeher, L.P. (2013). Trafficrelated occupational exposures to $\mathrm{PM}_{2.5}, \mathrm{CO}$, and VOCs in Trujillo, Peru. Int. J. Occup. Environ. Health 11: 276288. https://doi.org/10.1179/107735205800246073

Health and Executive (2013). Respiratory protective equipment at work: A practical guide Fourth Edition. http://www.hse.gov.uk/pubns/priced/hsg53.pdf

Ho, K.F., Lee, S.C. and Chiu, G.M.Y. (2002). Characterization of selected volatile organic compounds, polycyclic aromatic hydrocarbons and carbonyl compounds at a roadside monitoring station. Atmos. Environ. 36: 57-65. https://doi.org/10.1016/S1352-2310(01)00475-7

Ho, K.F., Ho, S.S.H., Lee, S.C., Louie, P.K.K., Cao, J.J. and Deng, W.J. (2013). Volatile organic compounds in roadside environment of Hong Kong. Aerosol Air Qual. Res. 13: 1331-1347. https://doi.org/10.4209/aaqr.2012.10.0278
Hoque, R.R., Khillare, P.S., Agarwal, T., Shridhar, V. and Balachandran, S. (2008). Spatial and temporal variation of BTEX in the urban atmosphere of Delhi, India. Sci. Total Environ. 392: 30-40. https://doi.org/10.1016/j.scit otenv.2007.08.036

Hosaini, P.N., Khan, M.F., Hamizah Mustafa, N.I., Amil, N., Mohamad, N., Jaafar, S.A., Mohd Nadzir, M.S. and Latif, M.T. (2017). Concentration and source apportionment of volatile organic compounds (VOCs) in the ambient air of Kuala Lumpur, Malaysia. Nat. Hazards. 85: 437-452. https://doi.org/10.1007/s11069-016-2575-7

Houot, J., Marquant, F., Goujon, S., Faure, L., Honoré, C., Roth, M.H., Hémon, D. and Clavel, J. (2015). Residential proximity to heavy-traffic roads, benzene exposure, and childhood leukemia-The GEOCAP Study, 2002-2007. Am. J. Epidemiol. 182: 685-693. https://doi.org/10.1093/ aje/kwv111

Hsieh, C.C. and Tsai, J.H. (2003). VOC concentration characteristics in Southern Taiwan. Chemosphere 50: 545556. https://doi.org/10.1016/S0045-6535(02)00275-8

Huang, Y., Ling, Z.H., Lee, S.C., Ho, S.S.H., Cao, J.J., Blake, D.R., Cheng, Y., Lai, S.C, Ho, K.F., Gao, Y., Cui, L. and Louie, P.K.K. (2015). Characterization of volatile organic compounds at a roadside environment in Hong Kong: An investigation of influences after air pollution control strategies. Atmos. Environ. 122: 809-818. https://doi.org/10.1016/j.atmosenv.2015.09.036

International Agency for Research on Cancer (IARC) (1987). Summaries \& evaluations: Benzene (Group 1). Lyon, International Agency for Research on Cancer, p. 120 (IARC Monographs on the Carcinogenicity of Chemicals to Humans, Supplement 7).

Jia, C., D'Souza, J. and Batterman, S. (2008). Distributions of personal VOC exposures: A population-based analysis. Environ. Int. 34: 922-931. https://doi.org/10.1016/j.envi nt.2008.02.002

Jorquera, H. and Rappenglück, B. (2004). Receptor modeling of ambient VOC at Santiago, Chile. Atmos. Environ. 38: 4243-4263. https://doi.org/10.1016/j.atmos env.2004.04.030

Junaidi, E.S., Jalaludin, J. and Tualeka, A.R. (2019). The evaluation of exposure to benzene among children in indoor environments: A review. Malaysian J. Med. Health Sci. 15: 151-155.

Kanjanasiranont, N., Prueksasit, T., Morknoy, D., Tunsaringkarn, T., Sematong, S., Siriwong, W., Zapaung, K. and Rungsiyothin, A. (2016). Determination of ambient air concentrations and personal exposure risk levels of outdoor workers to carbonyl compounds and BTEX in the inner city of Bangkok, Thailand. Atmos. Pollut. Res. 7: 268-277. https://doi.org/10.1016/j.apr.2015.10.008

Kanjanasiranont, N., Prueksasit, T. and Morknoy, D. (2017). Inhalation exposure and health risk levels to BTEX and carbonyl compounds of traffic policeman working in the inner city of Bangkok, Thailand. Atmos. Environ. 152: 111-120. https://doi.org/10.1016/j.atmosenv.2016.11.062

Kansal, A. (2009). Sources and reactivity of NMHCs and VOCs in the atmosphere: A review. J. Hazard. Mater. 166: 17-26. https://doi.org/10.1016/j.jhazmat.2008.11.048 
Karami, M.A., Fakhri, Y., Rezania, S., Alinejad, A.A., Mohammadi, A.A., Yousefi, M., Ghaderpoori, M., Saghi, M.H. and Ahmadpour, M. (2019). Non-carcinogenic health risk assessment due to fluoride exposure from tea consumption in Iran using Monte Carlo simulation. Int. J. Environ. Res. Public Health 16: 1-10. https://doi.org/10. 3390/ijerph16214261

Kerchich, Y. and Kerbachi, R. (2012). Measurement of BTEX (benzene, toluene, ethylbenzene, and xylene) levels at urban and semirural areas of Algiers City using passive air samplers. J. Air Waste Manage. Assoc. 62: 1370-1379. https://doi.org/10.1080/10962247.2012.712606

Kumar, A. and Víden, I. (2007). Volatile organic compounds: Sampling methods and their worldwide profile in ambient air. Environ. Monit. Assess. 131: 301-321. https://doi.org/ 10.1007/s10661-006-9477-1

Lai, C.H., Chen, K.S., Ho, Y.T., Peng, Y.P. and Chou, Y.M. (2005). Receptor modeling of source contributions to atmospheric hydrocarbons in urban Kaohsiung, Taiwan. Atmos. Environ. 39: 4543-4559. https://doi.org/10.1016/ j.atmosenv.2005.03.044

Lan, T.T.N. and Binh, N.T.T. (2012). Daily roadside BTEX concentrations in East Asia measured by the Lanwatsu, Radiello and Ultra I SKS passive samplers. Sci. Total Environ. 441: 248-257. https://doi.org/10.1016/j.scitoten v.2012.08.086

Lan, T.T.N. and Minh, P.A. (2013). BTEX pollution caused by motorcycles in the megacity of HoChiMinh. $J$. Environ. Sci. 25: 348-356. https://doi.org/10.1016/S100 1-0742(12)60045-X

Lan, T.T.N., Liem, N.Q. and Binh, N.T.T. (2013). Personal exposure to benzene of selected population groups and impact of commuting modes in Ho Chi Minh, Vietnam. Environ. Pollut. 175: 56-63. https://doi.org/10.1016/j.en vpol.2012.12.017

Latif, M.T., Hamid, H.H.A., Ahamad, F., Khan, M.F., Nadzir, M.S.M., Othman, M., Sahani, M., Wahab, M.I.A., Mohamad, N., Uning, R., Poh, S.C., Fadzil, M.F., Sentian, J. and Tahir, N.M. (2019). BTEX compositions and its potential health impacts in Malaysia. Chemosphere 237: 124451. https://doi.org/10.1016/j.chemosphere.2019.124 451

Lee, S.C., Chiu, M.Y., Ho, K.F., Zou, S.C. and Wang, X. (2002). Volatile organic compounds (VOCs) in urban atmosphere of Hong Kong. Chemosphere 48: 375-382. https://doi.org/10.1016/S0045-6535(02)00040-1

Li, B., Ho, S.S.H., Xue, Y., Huang, Y., Wang, L., Cheng, Y., Dai, W., Zhong, H., Cao, J. and Lee, S. (2017). Characterizations of volatile organic compounds (VOCs) from vehicular emissions at roadside environment: The first comprehensive study in Northwestern China. Atmos. Environ. 161: 1-12. https://doi.org/10.1016/j.atmosenv.2 017.04.029

Li, L., Li, H., Zhang, X., Wang, L., Xu, L., Wang, X., Yu, Y., Zhang, Y. and Cao, G. (2014). Pollution characteristics and health risk assessment of benzene homologues in ambient air in the North-eastern urban area of Beijing, China. J. Environ. Sc. 26: 214-223. https://doi.org/10.101 6/S1001-0742(13)60400-3
Liu, Y., Shao, M., Fu, L., Lu, S., Zeng, L. and Tang, D. (2008). Source profiles of volatile organic compounds (VOCs) measured in China: Part I. Atmos. Environ. 42: 62476260. https://doi.org/10.1016/j.atmosenv.2008.01.070

Majumdar, D., Dutta, C., Mukherjee, A.K. and Sen, S. (2008). Source apportionment of VOCs at the petrol pumps in Kolkata, India; exposure of workers and assessment of associated health risk. Transp. Res. D 13: 524-530. https://doi.org/10.1016/j.trd.2008.09.011

Manuela, C., Francesco, T., Tiziana, C., Assunta, C., Lara, S., Nadia, N., Giorgia, A., Barbara, S., Maria, F., Carlotta, C., Valeria, D.G., Pia, S.M., Gianfranco, T. and Angela, S. (2012). Environmental and biological monitoring of benzene in traffic policemen, police drivers and rural outdoor male workers. J. Environ. Monit. 14: 1542-1550. https://doi.org/10.1039/C2EM30120B

Masih, A., Lall, A.S., Taneja, A. and Singhvi, R. (2016). Inhalation exposure and related health risks of BTEX in ambient air at different microenvironments of a Terai zone in North India. Atmos. Environ. 147: 55-66. https://doi.org/10.1016/j.atmosenv.2016.09.067

Masih, A., Lall, A.S., Taneja, A. and Singhvi, R. (2017). Exposure profiles, seasonal variation and health risk assessment of BTEX in indoor air of homes at different microenvironments of a Terai province of Northern India. Chemosphere 176: 8-17. https://doi.org/10.1016/j.chemo sphere.2017.02.105

Miller, L., Xu, X., Wheeler, A., Atari, D.O., GrgicakMannion, A. and Luginaah, I. (2011). Spatial variability and application of ratios between BTEX in two Canadian cities. Sci. World J. 11: 2536-2549. https://doi.org/10.11 00/2011/167973

Miller, L., Xu, X., Grgicak-Mannion, A., Brook, J. and Wheeler, A. (2012). Multi-season, multi-year concentrations and correlations amongst the BTEX group of VOCs in an urbanized industrial city. Atmos. Environ. 61: 305-315. https://doi.org/10.1016/j.atmosenv.2012.07.041

Miri, M., Shendi, M.R.A., Ghaffari, H.R., Aval, H.E., Ahmadi, E., Taban, E., Gholizadeh, A., Aval, M.Y., Mohammadi, A. and Azari, A. (2016). Investigation of outdoor BTEX: Concentration, variations, sources, spatial distribution, and risk assessment. Chemosphere 163: 601609. https://doi.org/10.1016/j.chemosphere.2016.07.088

Miri, M., Alahabadi, A., Ehrampoush, M.H., Ghaffari, H.R., Sakhvidi, M.J.Z., Eskandari, M., Rad, A., Lotfi, M.H. and Sheikhha, M.H. (2018). Environmental determinants of polycyclic aromatic hydrocarbons exposure at home, at kindergartens and during a commute. Environ. Int. 118: 266-273. https://doi.org/10.1016/j.envint.2018.06.006

Mohammadi, A., Ghassoun, Y., Löwner, M.O., Behmanesh, M., Faraji, M., Nemati, S., Toolabi, A., Abdolahnejad, A., Panahi, H., Heydari, H. and Miri, M. (2020). Spatial analysis and risk assessment of urban BTEX compounds in Urmia, Iran. Chemosphere 246: 125769. https://doi.org/10. 1016/j.chemosphere.2019.125769

Mohammadyan, M., Golafshani, F.Y., Yousefinejad, R., Boogaard, P.J. and Heibati, B. (2016). Risk assessment of benzene among gas station refueling workers. Fresen. Environ. Bull. 25: 3563-3569. 
Monod, A., Sive, B.C., Avino, P., Chen, T., Blake, D.R. and Rowland, F.S. (2001). Monoaromatic compounds in ambient air of various cities: A focus on correlations between the xylenes and ethylbenzene. Atmos. Environ. 35: 135-149. https://doi.org/10.1016/S1352-2310(00)00 274-0

Muhammad, A.S., Jalaludin, J., Yusof, M. and Aqilah, N. (2012). Exposure to $\mathrm{PM}_{2.5}$ and respiratory health among traffic policemen in Kuala Lumpur. J. Occup. Saf. Health 9: 55-64.

Muhammad, N.S., Jalaludin, J. and Sundrasegaran, S. (2014). Exposure to respirable dust $\left(\mathrm{PM}_{10}\right)$ and respiratory health among traffic policemen in Selangor. Adv. Environ. Biol. 8: 199-206.

Na, K., Kim, Y.P. and Moon, K.C. (2003). Diurnal characteristics of volatile organic compounds in the Seoul atmosphere. Atmos. Environ. 37: 733-742. https://doi.org/10.1016/S1352-2310(02)00956-1

Norbäck, D., Hashim, J.H., Hashim, Z. and Ali, F. (2017). Volatile organic compounds (VOC), formaldehyde and nitrogen dioxide $\left(\mathrm{NO}_{2}\right)$ in schools in Johor Bahru, Malaysia: Associations with rhinitis, ocular, throat and dermal symptoms, headache and fatigue. Sci. Total Environ. 592: 153-160. https://doi.org/10.1016/j.scitoten v.2017.02.215

Okada, Y., Nakagoshi, A., Tsurukawa, M., Matsumura, C., Eiho, J. and Nakano, T. (2012). Environmental risk assessment and concentration trend of atmospheric volatile organic compounds in Hyogo Prefecture, Japan. Environ. Sci. Pollut. Res. 19: 201-213. https://doi.org/10. 1007/s11356-011-0550-0

Omidi, F., Dehghani, F., Fallahzadeh, R.A., Miri, M., Taghavi, M. and Eynipour, A. (2019). Probabilistic risk assessment of occupational exposure to volatile organic compounds in the rendering plant of a poultry slaughterhouse. Ecotoxicol. Environ. Saf. 176: 132-136. https://doi.org/10.1016/j.ecoenv.2019.03.079

Parra, M.A., González, L., Elustondo, D., Garrigó, J., Bermejo, R. and Santamaría, J.M. (2006). Spatial and temporal trends of volatile organic compounds (VOC) in a rural area of northern Spain. Sci. Total. Environ. 370: 157-167. https://doi.org/10.1016/j.scitotenv.2006.06.022

Pérez-Maldonado, I.N., Martínez, Á.C.O., Ruíz-Vera, T., Orta-García, S.T. and Varela-Silva, J.A. (2017). Human health risks assessment associated with polychlorinated biphenyls (PCBs) in soil from different contaminated areas of Mexico. Bull. Environ. Contam. Toxic. 99: 338343. https://doi.org/10.1007/s00128-017-2148-9

Rad, H.D., Babaei, A.A., Goudarzi, G., Angali, K.A., Ramezani, Z. and Mohammadi, M.M. (2014). Levels and sources of BTEX in ambient air of Ahvaz metropolitan city. Air. Qual. Atmos. Health 7: 515-524. https://doi.org/ 10.1007/s11869-014-0254-y

Raysoni, A.U., Stock, T.H., Sarnat, J.A., Chavez, M.C., Sarnat, S.E., Montoya, T., Holguin, F. and Li, W.W. (2017). Evaluation of VOC concentrations in indoor and outdoor microenvironments at near-road schools. Environ. Pollut. 231: 681-693. https://doi.org/10.1016/j.envpol.20 17.08.065
Road Traffic Volume Malaysia (RTVM) (2017). Kuala Lumpur: Highway Planning Division, Ministry of Works Malaysia.

Sahu, L.K., Pal, D., Yadav, R. and Munkhtur, J. (2016). Aromatic VOCs at major road junctions of a metropolis in India: Measurements using TD-GC-FID and PTRTOF-MS instruments. Aerosol Air Qual. Res. 16: 24052420. https://doi.org/10.4209/aaqr.2015.11.0643

Samadi, M.T., Shakerkhatibi, M., Poorolajal, J., Rahmani, A., Rafieemehr, H. and Hesam, M. (2019). Association of long-term exposure to outdoor volatile organic compounds (BTXS) with pro-inflammatory biomarkers and hematologic parameters in urban adults: A cross-sectional study in Tabriz, Iran. Ecotoxicol. Environ. Saf. 180: 152159. https://doi.org/10.1016/j.ecoenv.2019.05.008

Tolnai, B., Gelencsér, A., Gál, C. and Hlavay, J. (2000). Evaluation of the reliability of diffusive sampling in environmental monitoring. Anal. Chim. Acta. 408: 117122. https://doi.org/10.1016/S0003-2670(99)00878-8

Tsai, J.H., Chang, S.Y. and Chiang, H.L. (2012). Volatile organic compounds from the exhaust of light-duty diesel vehicles. Atmos. Environ. 61: 499-506. https://doi.org/10. 1016/j.atmosenv.2012.07.078

Tsai, J.H., Yao, Y.C., Huang, P.H. and Chiang, H.L. (2018). Fuel economy and volatile organic compound exhaust emission for motorcycles with various running mileages. Aerosol Air Qual. Res. 18: 3056-3067. https://doi.org/10. 4209/aaqr.2018.07.0264

Tung, H.D., Tong, H.Y., Hung, W.T. and Anh, N.T.N. (2011). Development of emission factors and emission inventories for motorcycles and light duty vehicles in the urban region in Vietnam. Sci. Total. Environ. 409: 27612767. https://doi.org/10.1016/j.scitotenv.2011.04.013

Tunsaringkarn, T., Siriwong, W., Rungsiyothin, A. and Nopparatbundit, S. (2012). Occupational exposure of gasoline station workers to BTEX compounds in Bangkok, Thailand. Int. J. Occup Med. Environ. Health 3: 117-125.

Tunsaringkarn, T., Prueksasit, T., Morknoy, D., Siriwong, W., Kanjanasiranont, N., Semathong, S., Rungsiyothin, A. and Zapaung, K. (2014). Health risk assessment and urinary biomarkers of VOCs exposures among outdoor workers in urban area, Bangkok, Thailand. Int. J. Environ. Pollut. Solut. 2: 32-46. https://doi.org/10.7726/IJEPS.20 14.1003

U.S. EPA (1989). Risk assessment: Guidance for superfund. In: Human Health Evaluation Manual (Part A), Interim Final, Vol 1. Office of Emergency and Remedial Response, U.S. Environmental Protection Agency, Washington DC.

U.S. EPA (1999). EPA Compendium Method TO-17. Determination of volatile organic compounds (VOCs) in ambient air using active sampling onto sorbent tubes. EPA 625/R-96/010b. Office of Research and Development, Cincinnati.

U.S. EPA (2007). Reference concentration for unit inhalation exposure (RfC), IRIS summary. Integrated Risk Information System.

U.S. EPA (2011). Exposure factors handbook 2011 edition 
(Final). EPA/600/R-090/052F. National Centre for Environmental Assessment. Office of Research and Development, Washington.

Wang, H.L., Jing, S.A., Lou, S.R., Hu, Q.Y., Li, L., Tao, S.K., Huang, C., Qiao, L.P. and Chen, C.H. (2017). Volatile organic compounds (VOCs) source profiles of on-road vehicle emissions in China. Sci. Total Environ. 607-608: 253-261. https://doi.org/10.1016/j.scitotenv.20 17.07.001

Wang, P. and Zhao, W. (2008). Assessment of ambient volatile organic compounds (VOCs) near major roads in urban Nanjing, China. Atmos. Res. 89: 289-297. https://doi.org/10.1016/j.atmosres.2008.03.013

Wang, X.M., Sheng, G.Y., Fu, J.M., Chan, C.Y., Lee, S.C., Chan, L.Y. and Wang, Z.S. (2002). Urban roadside aromatic hydrocarbons in three cities of the Pearl River Delta, People's Republic of China. Atmos. Environ. 36: 51415148. https://doi.org/10.1016/S1352-2310(02)00640-4

Williams, J. and Koppmann, R. (2007). Volatile organic compounds in the atmosphere: An overview. Blackwell Publishing Ltd. Oxford, UK.

Yao, Y.C., Tsai, J.H., Wang, I.T. and Tsai, H.R. (2017). Investigating criteria and organic air pollutant emissions from motorcycles by using various ethanol-gasoline blends. Aerosol Air Qual. Res. 17: 167-175. https://doi.org/10.4209/aaqr.2016.05.0174

Yao, Z., Shen, X., Ye, Y., Cao, X., Jiang, X., Zhang, Y. and He, K. (2015). On-road emission characteristics of VOCs from diesel trucks in Beijing, China. Atmos. Environ. 103: 87-93. https://doi.org/10.1016/j.atmosenv.2014.12.028
Yuan, B., Shao, M., Lu, S. and Wang, B. (2010). Source profiles of volatile organic compounds associated with solvent use in Beijing, China. Atmos. Environ. 44: 19191926. https://doi.org/10.1016/j.atmosenv.2010.02.014

Yurdakul, S., Civan, M. and Tuncel, G. (2013). Volatile organic compounds in suburban Ankara atmosphere, Turkey: Sources and variability. Atmos. Res. 120-121: 298-311. https://doi.org/10.1016/j.atmosres.2012.09.015

Zhang, J., Wang, T., Chameides, W.L., Cardelino, C., Blake, D.R. and Streets, D.G. (2008). Source characteristics of volatile organic compounds during high ozone episodes in Hong Kong, Southern China. Atmos. Chem. Phys. 8: 4983-4996. https://doi.org/10.5194/acp-8-4983-2008

Zhang, L., Huang, D., Yang, J., Wei, X., Qin, J., Ou, S., Zhang, Z. and Zou, Y. (2017). Probabilistic risk assessment of Chinese residents' exposure to fluoride in improved drinking water in endemic fluorosis areas. Environ. Pollut. 222: 118-125. https://doi.org/10.1016/j. envpol.2016.12.074

Zhou, J., You, Y., Bai, Z., Hu, Y., Zhang, J. and Zhang, N. (2011). Health risk assessment of personal inhalation exposure to volatile organic compounds in Tianjin, China. Sci. Total Environ. 409: 452-459. https://doi.org/10.1016/ j.scitotenv.2010.10.022

Received for review, November 12, 2019

Revised, June 10, 2020

Accepted, June 18, 2020 